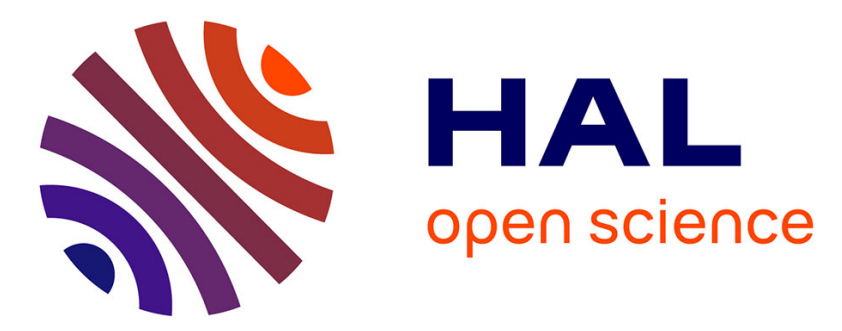

\title{
Selection of a genotype of Cotoneaster with a high level of resistance to Fire blight
}

Véronique Dupre, Roland Chartier, Marie-Noelle Brisset, Jean-Pierre Paulin

\section{To cite this version:}

Véronique Dupre, Roland Chartier, Marie-Noelle Brisset, Jean-Pierre Paulin. Selection of a genotype of Cotoneaster with a high level of resistance to Fire blight. 9. International Workshop on Fire blight, International Society for Horticultural Science (ISHS). INT., Oct 2001, Napler, New Zealand. hal-01600580

\section{HAL Id: hal-01600580 \\ https://hal.science/hal-01600580}

Submitted on 4 Jun 2020

HAL is a multi-disciplinary open access archive for the deposit and dissemination of scientific research documents, whether they are published or not. The documents may come from teaching and research institutions in France or abroad, or from public or private research centers.
L'archive ouverte pluridisciplinaire HAL, est destinée au dépôt et à la diffusion de documents scientifiques de niveau recherche, publiés ou non, émanant des établissements d'enseignement et de recherche français ou étrangers, des laboratoires publics ou privés.

\section{다(1)(2)}

Distributed under a Creative Commons Attribution - ShareAlike| 4.0 International 


\title{
Selection of a Genotype of Cotoneaster with a High Level of Resistance to Fire Blight
}

\author{
V. Bellenot-Kapusta \\ INRA - Unité d'Amélioration des \\ Espèces Fruitières et Ornementales \\ Centre d'Angers, 42 rue Georges Morel, \\ BP 57, 49071 Beaucouzé Cedex, France
}

\author{
R. Chartier, M.N. Brisset and J.P. Paulin \\ UMR Pathologie Végétale INRA/INH/UA \\ Centre d'Angers, 42 rue Georges Morel, \\ BP 57, 49071 Beaucouzé Cedex, France
}

Keywords: Erwinia amylovora, ornamental shrub, breeding

\begin{abstract}
Cotoneaster is, among the host plants of Erwinia amylovora, the genus which contains the highest number of 'susceptible' and 'very susceptible' genotypes to fire blight (circa 70\%). What is more, the number of very resistant cultivars - if any - is very limited. In this context we attempted to create a new genotype. Seeds were collected from the less susceptible varieties in our collection. About 555 plants derived from 27 different varieties were tested for three successive years by inoculation of one strain of $E$. amylovora (CFBP 1430). As a result, only a few genotypes showed no symptoms and among them one, derived from $C$. dammeri 'Eichholz', was finally selected with this strain. This genotype was confirmed as 'fairly resistant' under repeated inoculations with a number of strains of $E$. amylovora.
\end{abstract}

\section{INTRODUCTION}

Cotoneaster, a member of Rosaceae family, is a very common ornamental shrub and an important host for fire blight (Erwinia amylovora). Several investigations on fire blight susceptibility of species or cultivars have already been carried out in northern Europe (Jorgensen and Jensen, 1978; Zeller, 1979; Bouma, 1990). In 1984 a collection of 55 clones was planted in the south west of France, and shoot-inoculated with a suspension of E. amylovora (Lecomte and Cadic, 1992, 1993), in order to detect sources of resistance. Results showed great variability in fire blight susceptibility among the genus, but most of the tested cultivars were susceptible. Among the 55 taxons, 30 were selected for their lesser susceptibility, and seeds from open-pollination were collected from these clones. This paper presents the results of successive tests of susceptibility on the seedlings, performed in the greenhouse since 1996, which allowed the selection of a fairly resistant genotype (Fig. 1).

\section{MATERIALS AND METHODS}

\section{Evaluation of Progenies}

Seeds of progenies were sown in the greenhouse in spring 1995, after three months of stratification $\left(4^{\circ} \mathrm{C}\right)$. Seedlings were potted and grown outside. Plants were placed in the greenhouse at the end of summer and pruned to allow the growth of young shoots. After 4 - 6 weeks plants were suitable for inoculation. Inoculation was performed by dipping scissors in a bacterial suspension and then cutting the two younger unfolded leaves at the top of three growing shoots per plant. From 1996 to 1998, 555 plants from 27 progenies were inoculated two or three times with a common strain of E. amylovora, CFBP $1430\left(10^{6} \mathrm{cfu} / \mathrm{ml}\right.$ and $10^{8} \mathrm{cfu} / \mathrm{ml}$ on the last date), and compared with known varieties as standards. Between each date of inoculation, plants were pruned to eliminate the infected branches and to allow the growth of new shoots. Plant susceptibility was evaluated by measuring the length of the necrosis on each shoot after three weeks, in comparison to final shoot length. Susceptibility was assessed as the percentage of diseased shoots, and the percent length of necrosis in relation to length of inoculated shoots. Plants with no necrosis, or necrosis limited to the inoculation point, were selected 
for further testing.

\section{Test of Four Selections with Three Strains}

In a second step, four selected plants were propagated by cuttings and the clones were inoculated with three strains of $E$. amylovora to evaluate their susceptibility in comparison with their female parents and other known cultivars (Fig. 2). Each clone was inoculated with strains CFBP 1430, CFBP 3049 and CFBP 3012 (10 cfu/ml) on several shoots for each strain. We replicated this inoculation at least twice during winter 1998-99, in the conditions previously described. This led to the selection of clone 1518.

\section{Evaluation of the Pre-selection 1518 with 22 Strains}

In a third step the selected clone 1518 was challenged with 22 strains (Table 2) inoculated by injection of bacterial suspension $\left(10^{7} \mathrm{cfu} / \mathrm{ml}\right)$ just below the growing apex with a syringe (Fig. 3). Inoculations were performed at least twice between November 1999 and May 2001.

\section{RESULTS AND DISCUSSION}

\section{Evaluation of Progenies}

Due to variable germination, and variable vigour of plants, only 27 out of the 30 progenies were successfully inoculated, on a variable number of actively growing seedlings per progeny. From this test, we selected 12 plants originating from three different progenies, which had few or no symptoms (Table 1). Most of these plants were derived from slowly growing and small leaf types such as C. microphyllus 'Excellenz', and C. microphyllus cochleatus. Only two were derived from C. dammeri 'Eichholz', which is a more vigorous cultivar.

\section{Test of Four Selections with Three Strains}

Out of these 12 plants, four were selected on the basis of their ornamental and propagation potential; they were multiplied to obtain clones. Two derived from $C$. microphyllus 'Excellenz' (0808, 0832), one from C. microphyllus cochleatus (1108) and one from C. dammeri 'Eichholz' (1518). After inoculation with the three strains, strong differences between clones were observed which varied according to the bacterial strain used (Fig. 2). Plants derived from C. microphyllus appeared far more susceptible in this experiment than in previous experiments. This was probably due to an average higher vigour of the plants in this trial, which allowed a better expression of the symptoms. The mean length of necrosis indicated that most clones were more susceptible to strain CFBP 1430 than to CFBP 3049 or CFBP 3012, and that clones derived from C. dammeri 'Eichholz' $(1518,1526,1585))$ were less susceptible. The clone $(1518)$ seemed to be fairly resistant to the three strains, as necroses were limited to the inoculation point.

\section{Evaluation of the Pre-selection 1518 with 22 Strains}

The results presented in Figure 3 show that most cultivars were susceptible to the majority of the strains, with high percentages of infected shoots and length of necrosis. Clone 1518 appeared to behave like 'Streibs Findling'. However, it showed very limited symptoms with most of the strains: with four strains only, the relative length of necrosis was higher than $25 \%$. In addition, clone 1518 was very vigorous with good shoot growth, and therefore the limitation of the symptoms could not be explained by physiological parameters, as observed in the literature (Bouma, 1990; Lecomte and Cadic, 1993). Consequently, this clone was tolerant and possibly resistant to most of the strains when compared with the controls.

Clone 1518, derived from C. dammeri 'Eichholz', could then become a new commercial variety. To confirm this we are presently assessing its horticultural and ornamental characteristics in the field and its behaviour under natural conditions of infection. 


\section{ACKNOWLEDGEMENTS}

We want to thank for his technical help in all this work, our colleague Albert Renoux who passed away before the end of this experiment, and all the colleagues, working at the INRA experimental greenhouse, who performed plant cultivation.

\section{Literature Cited}

Bouma, A.S. 1990. Testing Cotoneaster, Crataegus and Pyracantha for fire blight susceptibility in The Netherlands. In : Fire blight of Pomoidae (Erwinia amylovora, Burrill, Winslow et al.). Applied Research in Europe (1978-1988). EUR12601.ECSC.EEC.EAEC., Brussels, Luxemburg, 1990:280pp.

Jorgensen, H.A. and Jensen, A.1978. Natural infection of host plants in the Danish "fire blight" gardens. Acta Hort. 86:11-14.

Lecomte, P. and Cadic, A. 1992. Sensibilité au feu bactérien des cotoneasters. PHM Revue Horticole 324:26-29.

Lecomte, P. and Cadic, A. 1993. Further results on shoot susceptibility of Cotoneaster to fire blight. Acta Hort. 338:407-411.

Zeller, W. 1979. Resistance and resistance breeding in ornamentals. OEPP/EPPO Bull. $9: 35-44$ 


\section{$\underline{\text { Tables }}$}

Table 1. Evaluation of susceptibility to fire blight of progenies of Cotoneaster after greenhouse inoculations with E. amylovora strain CFBP1430.

\begin{tabular}{|lcc|}
\hline $\begin{array}{l}\text { female parent } \\
\text { of the progeny }\end{array}$ & $\begin{array}{c}\text { number of inoculated } \\
\text { seedlings }\end{array}$ & $\begin{array}{c}\text { number (\%) of selected } \\
\text { plants after 3 inoculations }\end{array}$ \\
\hline C. adpressus & 13 & 0 \\
\hline C. amoenus & 14 & 0 \\
\hline C. apiculatus & 10 & 0 \\
\hline C. conspicuus 'Decorus' & 24 & 0 \\
\hline C. dammeri & 30 & 0 \\
\hline C. dammeri 'Coral Beauty' & 30 & 0 \\
\hline C. dammeri 'Eichholz' & 98 & $\mathbf{2}(2)$ \\
\hline C. dammeri 'Major' & 29 & 0 \\
\hline C. dammeri 'Skogholm' & 16 & 0 \\
\hline C. dielsianus & 10 & 0 \\
\hline C. distichus & 15 & 0 \\
\hline C. franchetii & 10 & 0 \\
\hline C. franchetii sternianus & 13 & 0 \\
\hline C. hebephyllus & 10 & 0 \\
\hline C. horizontalis perpusillus & 7 & 0 \\
\hline C. horizontalis 'Robustus' & 21 & 0 \\
\hline C. melanocarpus & 6 & 0 \\
\hline C. microphyllus cochleatus & 20 & $\mathbf{1}(5)$ \\
\hline C. microphyllus 'Excellenz' & 32 & $9(28)$ \\
\hline C. microphyllus melanotrichus & 2 & 0 \\
\hline C. microphyllus thymifolius & 6 & 0 \\
\hline C. nitidus & 11 & 0 \\
\hline C. roseus & 3 & 0 \\
\hline C. salicifolius 'Parkteppish' & 29 & 0 \\
\hline C. salicifolius 'Red Flare' & 10 & 0 \\
\hline C. salicifolius 'Scarlet Leader' & & 0 \\
\hline C. zabelii & 29 & 0 \\
\hline
\end{tabular}


Table 2. Origin of strains of Erwinia amylovora.

\begin{tabular}{|lll|}
\hline Strain $(*)$ & Host plant & Origin \\
\hline $17 / 14$ & Sorbus & France (C. Audusseau) \\
\hline $674 / 94$ & Pyrus & Austria (M. Keck) \\
\hline 9/61 & Sorbus & France (C. Audusseau) \\
\hline CFBP 1197 & Crataegus sp. & UK \\
\hline CFBP 1367 & Crataegus oxyacantha & France \\
\hline CFBP 1430 & Crataegus & France \\
\hline CFBP 2301 & Pyracantha & France \\
\hline CFBP 2582 & Pyrus sp. & Ireland \\
\hline CFBP 2585 & Sorbus sp. & Ireland \\
\hline CFBP 2586 & Pyracantha sp. & Ireland \\
\hline CFBP 3012 & Crataegus monogyna & Belgium \\
\hline CFBP 3020 & Pyrus communis & Netherlands \\
\hline CFBP 3039 & Malus sylvestris & UK \\
\hline CFBP 3043 & Pyracantha angustifolia & UK \\
\hline CFBP 3049 & Malus domestica & Canada \\
\hline CFBP 3050 & Malus domestica & Canada \\
\hline CFBP 3060 & Pyrus sp. & Greece \\
\hline CFBP 3113 & Pyracantha sp. & Germany \\
\hline CFBP 3791 & Prunus salicina & USA \\
\hline CFBP 3792 & Prunus salicina & USA \\
\hline CFBP 3793 & Prunus salicina & USA \\
\hline EA 115 & Malus domestica & Germany (W. Zeller) \\
\hline
\end{tabular}

$\left({ }^{*}\right)$ CFBP : Collection Française de Bactéries Phytopathogènes (INRA-Angers) 


\begin{tabular}{|lll|}
\hline Year : & \\
$86-91$ & $\quad$ Field inoculation : 55 taxons $\times 1$ strain (CFBP 1430) \\
$96-98$ & $\frac{\text { Greenhouse inoculations }}{\text { Test of } 27 \text { progenies } \times 1 \text { strain (CFBP 1430) }}$ \\
& $\Downarrow$ & \\
$98-99$ & & Test of 4 pre-selected clones $\times 3$ strains (CFBP 1430, 3012, 3049) \\
$99-01$ & & Test of clone $1518 \times 22$ strains (see Table 2)
\end{tabular}

Fig. 1. Successive steps for fire blight selection 


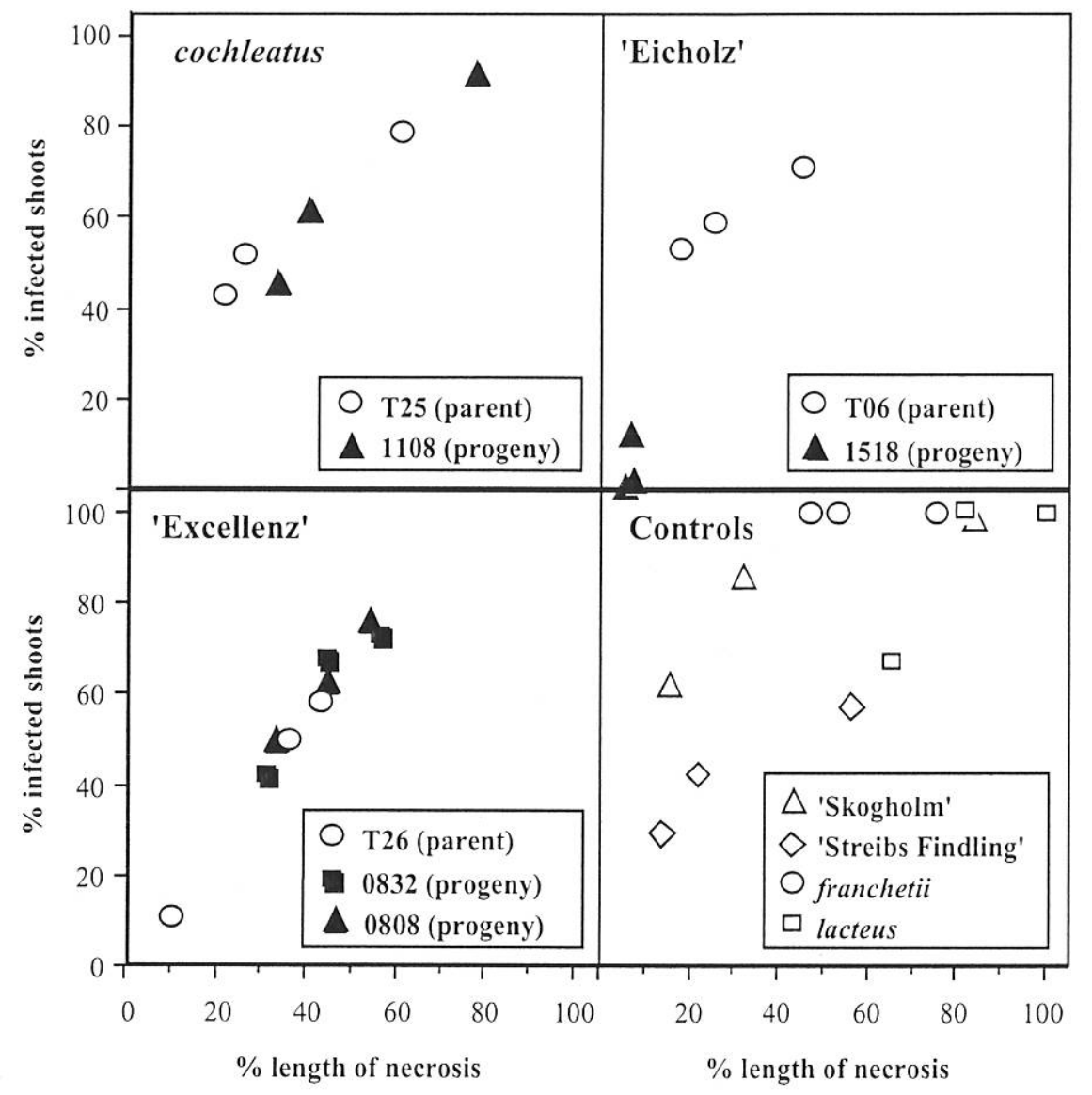

Fig. 2. Susceptibility of four pre-selected clones, compared to their parents (each dot represents the mean results obtained with one of the three strains for the two dates). 


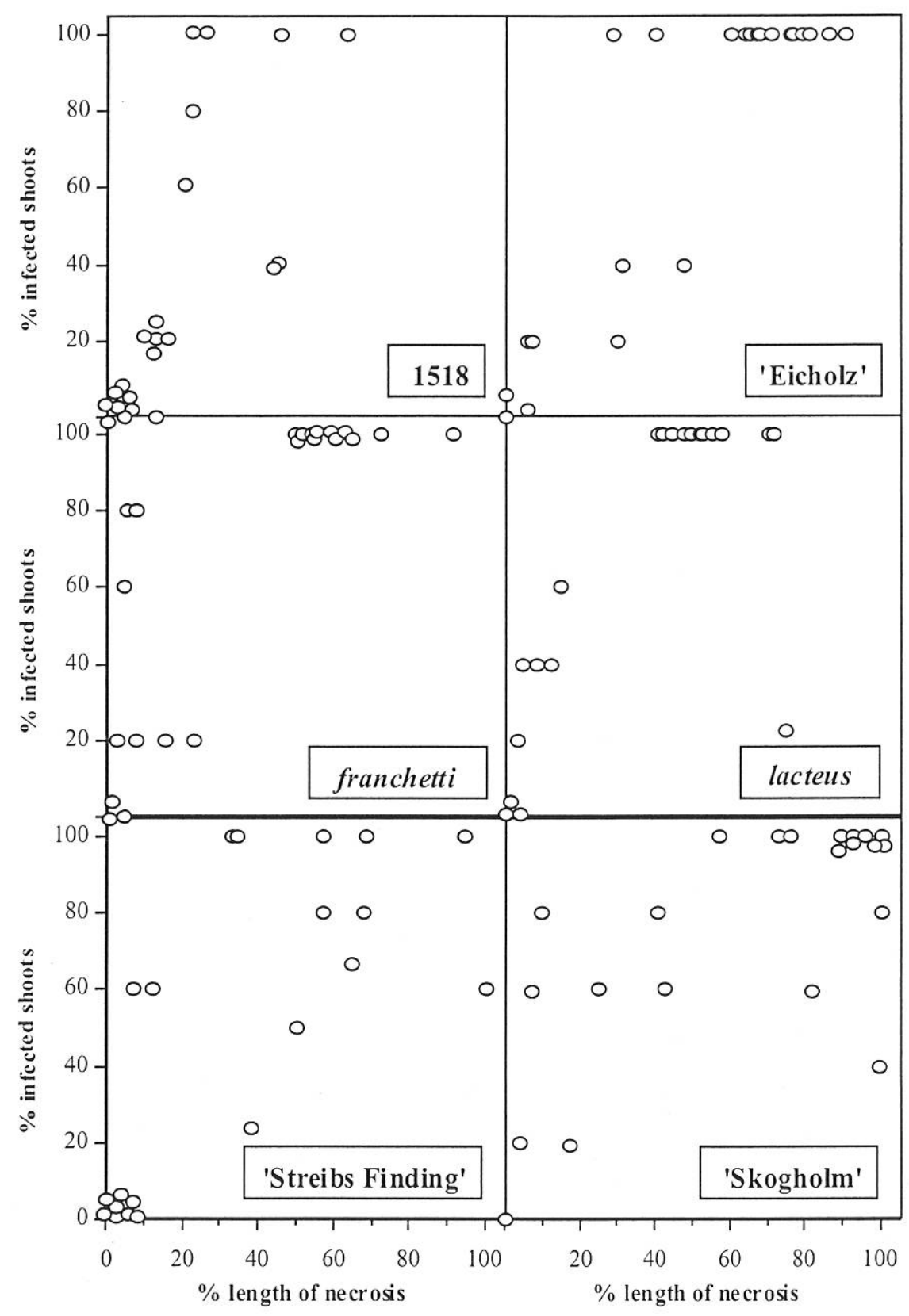

Fig. 3. Inoculation of clone 1518, compared with known cultivars (each dot represents the results obtained with one of the 22 strains) 